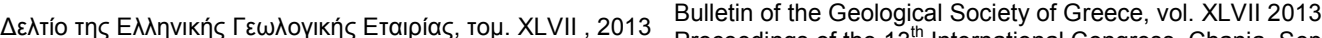
Proceedings of the $13^{\text {th }}$ International Congress, Chania, Sept.

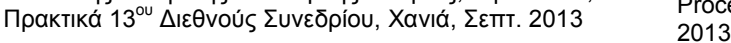

\title{
A NEW OCCURRENCE OF PYROPHANITE FROM THE AMPHIBOLITE-HOSTED SKARN IN WESTERN KIMMERIA, XANTHI, NORTHERN GREECE
}

\author{
Voudouris P. ${ }^{1}$, Xinou A. ${ }^{2}$, Kanellopoulos C. ${ }^{1}$, Kati M. ${ }^{1}$, Mavrogonatos C. ${ }^{1}$, \\ and Lyberopoulos $\mathbf{P}^{1}$.
}

\footnotetext{
1. National and Kapodistrian University of Athens, Faculty of Geology and Geoenvironment, Department of Mineralogy and Petrology,voudouris@geol.uoa.gr, ckanellopoulos@gmail.com, kmavrogon@geol.uoa.gr,kati@geol.uoa.gr,

${ }^{2}$ TITANAE, Athens, xinouk@titan.gr
}

\begin{abstract}
A new occurrence of pyrophanite $\left(\mathrm{MnTiO}_{3}\right)$ in Greece is described from the garnetclinopyroxene-wollastonite exoskarn of western Kimmeria. Hostrock of the pyrophanite-bearing skarn is amphibolite (retrogressed eclogites) of the Nestos suture zone in the Rhodope massif. In addition endo- and exo-skarns occur both in the Xanthi granodiorite and the surrouding marbles and consinst of diopside-vesuvianitequartz and wollastonite-garnet-calcite-quartz respectively. Pyrophanite formed in the prograde stage, together with garnet, pyroxene, wollastonite, titanite, zircon, rutile, thorite and ouranothorianite. Retrograde minerals are quartz, epidote, calcite, hematite, and sulfides. Chlorite-geothermometry revealed temperatures in the range from 300 to $350{ }^{\circ} \mathrm{C}$ for the retrograde event. Calcic garnets (andraditegrossular solid solutions) from the prograde amphibolite-hosted skarn are chemically zoned with either isotropic or anisotropic cores surrounded by non-cubic anisotropic rims, thus suggesting chemical disequilibrium or disordering phenomena during crystal growth. The pyrophanite crystals are included in titanite and are accompanied by $U$-rich thorium minerals (uranothorianite, thorite) and by rutile. Electron microprobe analyses indicate that the studied pyrophanites are solid solutions between end-member pyrophanite and ilmenite, with isomorphous substitution of $\mathrm{Mn}^{2+}$ by $\mathrm{Fe}^{2+}$. No Mg has been detected (geikielite end-member). The alteration of pyrophanite and rutile to titanite suggests an increase of $\mathrm{fO}_{2}$ values of the fluids, probably due to increased incursion of meteoric waters to the system. The assemblage thorite, uranothorianite, pyrophanite and zircon indicates a magmatic contribution from the Xanthi granodiorite.

Key words: pyrophanite, thorite - uranothorianite, skarn, Kimmeria, Rhodope.
\end{abstract}

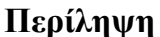

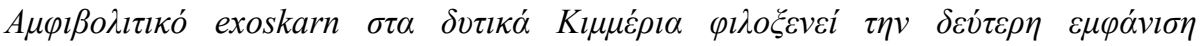

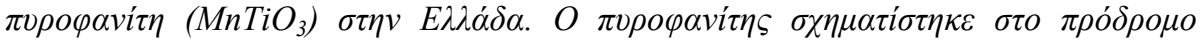

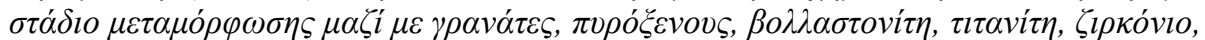

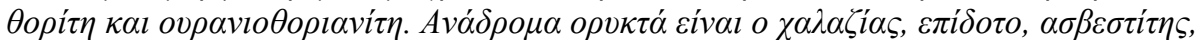

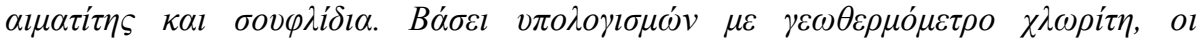

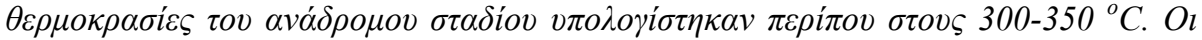

XLVII. No $1-487$ 


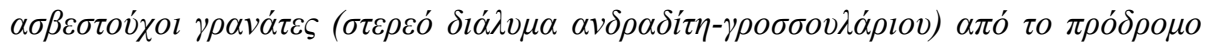

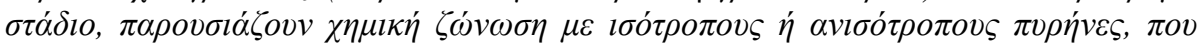

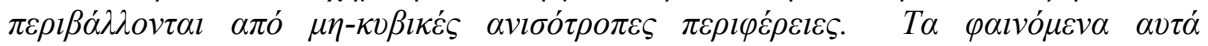

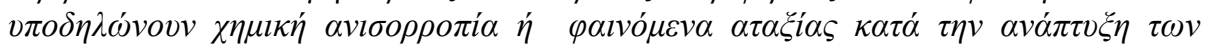

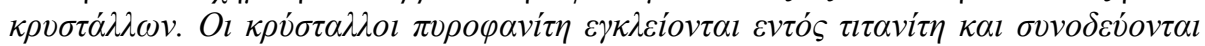

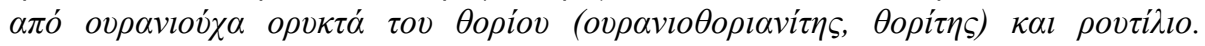

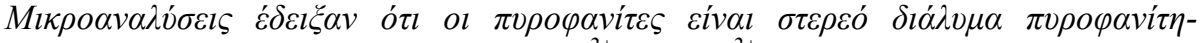

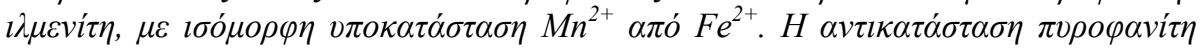

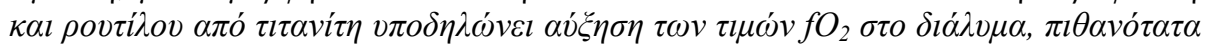

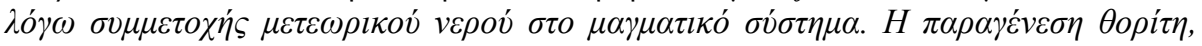

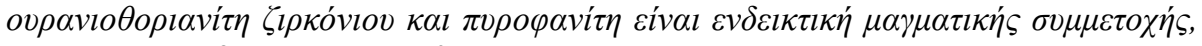

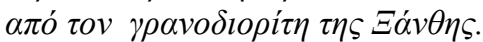

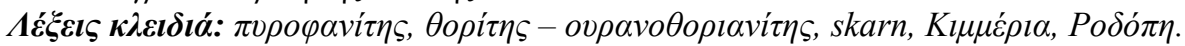

\section{Introduction}

Pyrophanite with ideal formula $\mathrm{MnTiO}_{3}$ is a relatively rare mineral and member of the ilmenite group (Zaccarini et al., 2004). It crystallizes in the trigonal system and is one end member of the rhombohedral phases in the quaternary system $\mathrm{FeTiO}_{3}-\mathrm{MgTiO}_{3}-\mathrm{MnTiO}_{3}-\mathrm{Fe}_{2} \mathrm{O}_{3}$ (ilmenitegeikielite-pyrophanite-hematite). Pyrophanite as a manganese titanium oxide mineral is the $\mathrm{Mn}$ rich analogue of ilmenite. Pyrophanite crystals occur as subhedral aggregates or microscopic grains. They are black, opaque, and have metallic luster. Pyrophanite was originally described by Hamberg (1890) who first found the mineral in drusy cavities of manganese ore at the Harstig mine, Pajsberg, Sweden. The associated minerals are garnet, ganophyllite, and calcite. Until 1940, only other two occurrences of pyrophanite were known, in Brazil and Wales. Pyrophanite can be present in a wide range of environments ranging from gneisses, granitic rocks, alkaline complexes and karbonatites, to serpentinite and even in meteorites. It can be also associated with epithermal and hydrothermal manganese deposits, metamorphic deposits rich in zinc and manganese and occasionally with banded iron formations (BIF) (Zaccarini et al., 2004). In Greece, pyrophanite has been described for the first time from Mn-bearing metasedimentary rocks in Ikaria Island (Iliopoulos, 2005).

Amphibolites (retrogressed eclogites) within the Nestos Suture Zone (Krenn et al. 2008) of the Rhodope metamorphic complex (western Kimmeria), host a garnet-clinopyroxene-wollastonite exoskarn. The mineralogical study of the exoskarn revealed a complex mineralogical composition and among the other minerals, the occurrence of pyrophanite $\left(\mathrm{MnTiO}_{3}\right)$. The mineralization contains U-rich thorium minerals (uranothorianite, thorite) and calcic garnets (andradite-grossular solid solution). The aim of the present paper is to study the mineralogy and mineral chemistry of the garnet-clinopyroxene-wollastonite exoskarn of western Kimmeria, highlighting the second occurrence of pyrophanite in Greece.

\section{Regional Geological Setting}

The Hellenides, part of the Alpine-Himalayan orogen, can be considered an accretionary orogen, where a late Precambrian to late Jurassic evolution was marked by the opening and closure of ocean basins and continental crust formation in the accompanying subduction zones (Papanikolaou 1984; Reischmann and Kostopoulos, 2007). A Permo-Carboniferous igneous event (known from the Pelagonian Zone, the Rhodope Massif and the Attico-Cycladic Zone) documents an active continental margin evolution in the Precambrian-Silurian basement of the Hellenides (Reischmann and Kostopoulos, 2007). After the closure of the Vardar Ocean, shortening and syn-orogenic exhumation of HP-LT rocks occurred during the late Cretaceous-Eocene, before an acceleration of slab retreat changed the subduction regime and caused the collapse of the Hellenic mountain belt

$\underline{\text { XLVII. No } 1-488}$ 
and the thinning of the Aegean Sea from the middle Eocene/late Oligocene to the present (Jolivet et al. 2010). During this post-orogenic episode large-scale detachments formed, which exhumed metamorphic core complexes, in a back-arc setting (Cyclades and Rhodope) (Gautier and Brun, 1994). Turpaud and Reischmann (2010) subdivided the central Rhodope Massif into the upper Thracia Terrane, dominated by Permo-Carboniferous orthogneisses and Triassic marbles, and the lower Rhodope Terrane, consisting of Late Jurassic orthogneisses. These two terranes can be interpreted as lower and upper continental plates, which were tectonically superimposed during Alpine N-S directed continent-continent collision and subsequent SW directed nappe stacking (Ricou et al. 1998; Krenn et al. 2010). The two terranes are separated by the Nestos Suture Zone, which is well exposed north of the SW-directed thrust fault (Nestos thrust, Papanikolaou and Panagopoulos 1981; Barr et al. 1999). The rocks within the suture zone experienced HP to UHP metamorphism with subsequent high-grade amphibolite-facies overprint, as recorded in metasediments and mafic rocks (Mposkos annd Kostopoulos, 2001; Liati and Seidel, 1996; Mposkos and Krohe, 2006). Recent studies on metamorphic zircons from the suture zone give ages of 171 Ma related to a posteclogite facies metamorphic stage and an age of $79 \mathrm{Ma}$ attributed to amphibolite-facies metamorphism (Bauer et al. 2007). The eclogite-facies metamorphic event took place at $19 \mathrm{kbar}$ and $700{ }^{\circ} \mathrm{C}$ (Liati and Mposkos, 1990), and was followed by granulite facies- $\left(\mathrm{P}>15 \mathrm{kbar}, \mathrm{T}>800{ }^{\circ} \mathrm{C}\right)$ and amphibolite-facies overprint $\left(8-11 \mathrm{kbar}\right.$ and $\left.580-690{ }^{\circ} \mathrm{C}\right)$ as recorded from relict kyanite-eclogites (Liati and Seidel, 1996). Ultramafic rocks occur a boudins associated with amphibolites (Barr et al., 1999). In the Rhodope Massif (Bulgaria and Greece), late Cretaceous-Tertiary exhumation of deep metamorphic rocks along detachment faults, resulted in the formation of metamorphic core complexes, supra-detachment sedimentary basins, and widespread Late Eocene to Early Miocene basic to felsic magmatism (Marchev et al., 2005).

\section{Local Geological Setting}

The Oligocene age, I-type, Xanthi plutonite (Del Moro et al., 1988) penetrates marbles, gneisses and amphibolites of both the Thracia and Rhodope terranes, as well as of the Nestos Suture Zone. Its petrological composition varies significantly, but the most common petrographic types are granodiorite, monzonite and in smaller percentage gabbroic rocks (Sergi, 1997). The Xanthi plutonite is also characterized by many aplitic and pegmatitic veins that crosscut the igneous body in various locations. The granodioritic bodies consist of quartz, feldspars, hornblende and biotite with minor epidote, apatite, zircon and magnetite. The monzonite contains feldspars, quartz, biotite and pyroxene, while gabbros are characterized by plagioclase, pyroxenes and some olivine.

A thermo-metamorphic halo of considerable thickness is present around the contact of Xanthi plutonite and the surrounding rocks (e.g. marbles, gneisses and amphibolites). Estimated maximum P-T conditions are about $750^{\circ} \mathrm{C}$ and $3 \mathrm{~kb}$ (Liati, 1986; Georgiadis et al. 2012). The studied skarn outcrop occurs about $3 \mathrm{~km} \mathrm{NW}$ of the Kimmeria village and is hosted within amphibolites (and marbles) of the Nestos Suture Zone (Figure 1). Both prograde and retrograde minerals are present and include calc-silicate minerals (e.g. garnet, epidote, wollastonite, diopside, actinolite, scapolite), sulfides (e.g. chalcopyrfigite, pyrite), oxides (e.g. magnetite, hematite, scheelite), as well as secondary phases like azurite, malachite and limonite.

\section{Materials and Methods}

Fourty-five thin and polished sections of skarn samples and the host rock were studied ny optical and a Jeol JSM 5600 scanning electron microscope, equipped with back-scattered imaging facilities, at the Department of Geology and Geoenvironment, University of Athens. The operating conditions were as follows: accelerating voltage $20 \mathrm{kV}$, beam current $0.5 \mathrm{nA}$, time of measurement $50 \mathrm{sec}$ and beam diameter $<2 \mu \mathrm{m}$. The spectra were processed using the ZAF program (3 interactions). The microprobe analyses were conducted on polished sections of the samples after carbon coating. 

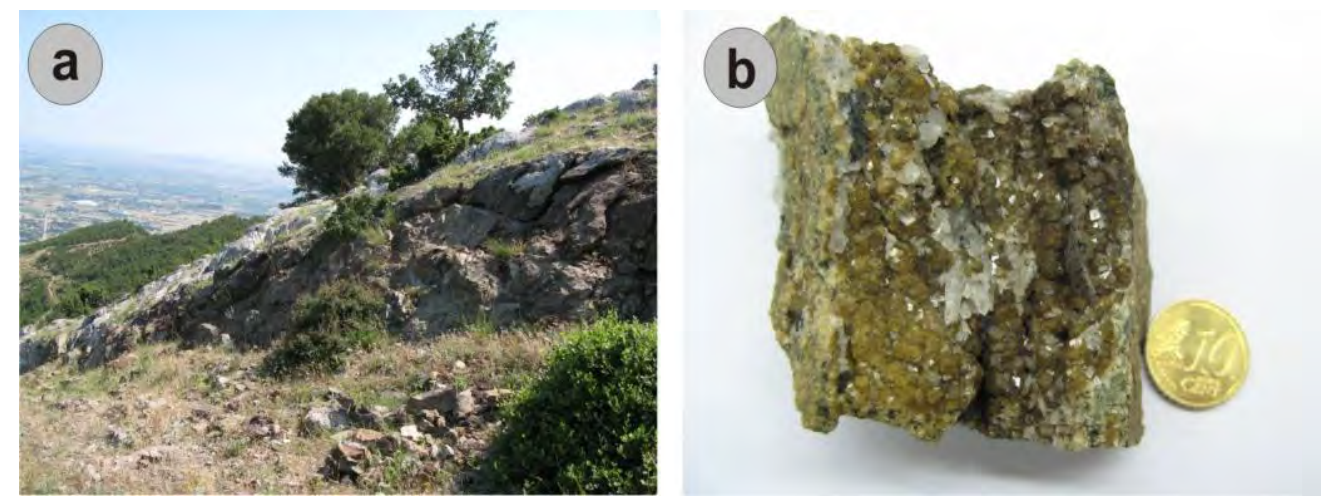

Figure 1 - (a) Wollastonitic-garnetitic skarn developed in amphibolites (and marbles) in the vicinity of the granodiorite. (b) Hand specimen of amphibolite-hosted skarn with euhedral crystals of green garnet and quartz.

\section{Analytical Data}

\subsection{Mineralogy and Mineral Chemistry}

Garnet group minerals are major constituents of the amphibolite-hosted wollastonitic skarn of Kimmeria. Garnets occur in idiomorphic light green-yellowish to emerald-colored rhombic dodecahedral crystals (Figure 1b). Initial deposition of garnet with wollastonite, clinopyroxene, titanite, pyrophanite and thorium-bearing phases during the prograde stage, was followed by the deposition of a retrograde assemblage consisting of quartz, epidote, chlorite and calcite (Figure 2). The garnets are chemically zoned with individual zones ranging in composition between andradite and grossular (Table 1; Figures 1a,b; 3a). Mn (up to 0.4 apfu) substitutes for $\mathrm{Mg}$ and $\mathrm{Fe}$ in the structure. Isotropic domains in the cores of the crystals and non-cubic anisotropic rims and vice-versa are common features.

Clinopyroxene and wollastonite accompany garnets in the prograde skarn assemblage (Figure 2a, d-f). Representative microanalyses of clinopyroxene are presented in Table 1 and ploted in Figure $3 b$. The analyzed clinopyroxenes are solid solutions between diopside-hedenbergite (Figure 3b).

Epidote group mineral in euhedral crystals, reaching length of up to $10 \mathrm{~cm}$, with dark green color and intense lustre, is a common constituent in the Kimmeria skarn. Epidote is a retrograde mineral postdating wollastonite and garnet and clinopyroxene and is associated with other retrograde phases as quartz, actinolite and calcite (Figure 2e). The REE-bearing allanite contains up to 7.63 wt. $\% \mathrm{La}_{2} \mathrm{O}_{3}$ and up to 12.5 wt. $\% \mathrm{Ce}_{2} \mathrm{O}_{3}$. Representative microanalyses of allanite are presented in Table 1.

Chlorite in characteristic radiating aggregates with intense green color replaces garnet (Figure 2b). Representative microanalyses are presented in Table 1 and the data are ploted in Figure 3c. The Kimmeria chlorites are classified as Fe-clinochlores (Figure 3c). In order to obtain crystallization temperatures of the studied chlorites we applied the geothermometer of Cathelinau (1988), which correlates temperature with chlorite chemical composition based on the relationship $\mathrm{T}\left({ }^{\circ} \mathrm{C}\right)=-$ $61.92+321.98\left(\mathrm{Al}^{\mathrm{IV}}\right)$. According to this geothermometer the formation temperatures of studied chlorites range from $292^{\circ}$ to $340^{\circ} \mathrm{C}$.

Chromite occurs is contact to uranothorianite as small euhedral crystals included in garnets (Figure $2 \mathrm{c})$. 
Chalcopyrite accompanies pyrophanite, rutile being part of the prograde mineral assemblage (Figure 2f).
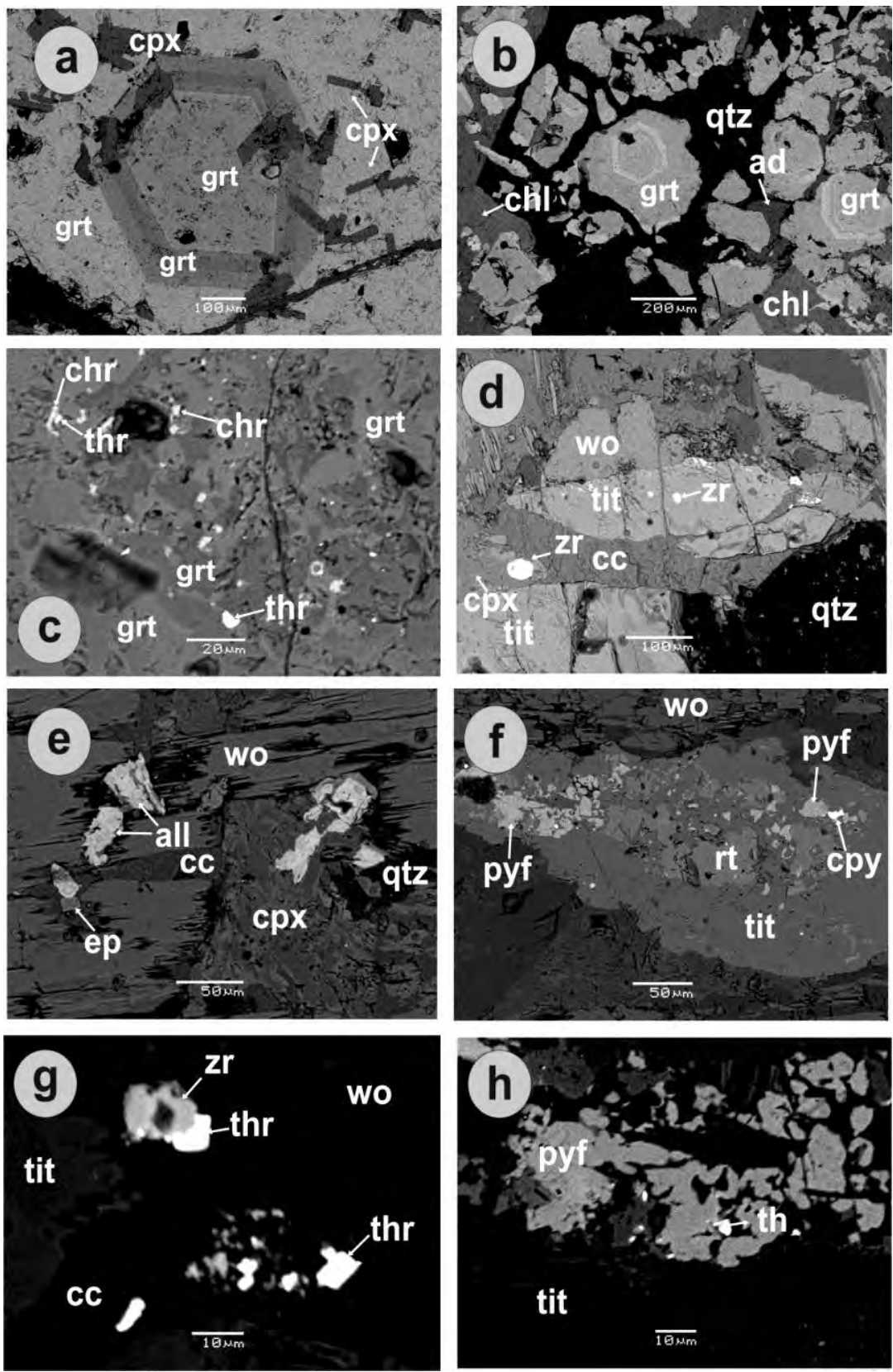

Figure 2 - Microphotographs demonstrating mineralogical assemblages of the Kimmeria skarn (SEM-BSE images). (a) Idiomorphic zoned garnet crystal (gnt) intergrown with clinopyroxene (cpx). (b) Garnets (gnt) replaced by retrograde quartz (qtz), chlorite (chl) and adularia (ad). (c) Chromite (chr) and uranothorianite (thr) included in garnet (gnt). (d) Titanite (tit) including zircon (zr) replaced by calcite (cc). Wollastonite (wo) and clinopyroxene (cpx) are also present. (e) Allanite (all), epidote (ep), quartz (qtz) and calcite (cc) postdate wollastonite (wo) and clinopyroxene (cpx). (f) Titanite (tit) crystal with inclusions of pyrophanite 
(pyf), rutile (rt) and chalcopyrite (cpy) replacing wollastonite (wo). (g) Uranothorianite (thr) and zircon (zr) associated with calcite (cc) and titanite (tit) postdating wollastonite (wo). (h) Enlargement of Figure $2 f$ (left part): pyrophanite (pyf) and thorite (th) included in titanite (tit).

Titanite in idomorphic crystals up to $300 \mu \mathrm{m}$ in length is intergrown with garnets and includes pyrophanite and rutile (Figure 2d).

Scheelite, hematite, scapolite and adularia, the hydrothermal variety of K-feldspar (Dimitriadis and Soldatos, 1978; Figure 2b), are additional retrograde minerals of the Kimmeria skarn (Skarpelis and Liati 1991).

Table 1. Representative microanalyses of garnet (1-3), chlorite (4-6), pyroxene (7-8) and REE-bearing epidote (9-10).

\begin{tabular}{cccc}
\hline $\mathbf{W t} \%$ & $\mathbf{1}$ & $\mathbf{2}$ & $\mathbf{3}$ \\
\hline $\mathbf{S i O}_{\mathbf{2}}$ & 39.77 & 37.73 & 36.95 \\
$\mathbf{T i O}_{\mathbf{2}}$ & 0.03 & 2.86 & 3.22 \\
$\mathbf{A l}_{\mathbf{2}} \mathbf{O}_{\mathbf{3}}$ & 20.21 & 6.02 & 9.09 \\
$\mathbf{F e O}$ & 3.68 & 19.28 & 14.56 \\
$\mathbf{C r}_{\mathbf{2}} \mathbf{O}_{\mathbf{3}}$ & 0.05 & 0.73 & 0.33 \\
$\mathbf{M n O}$ & 1.15 & 0.10 & 0.07 \\
$\mathbf{M g O}$ & bd & 0.23 & 0.51 \\
$\mathbf{C a O}$ & 34.55 & 33.59 & 34.06 \\
$\mathbf{N a}_{\mathbf{2}} \mathbf{O}$ & bd & 0.26 & 0.16
\end{tabular}

Total 99.43100 .8098 .95

24(O) $24(0) 24(0)$

Si $\quad 3.0393 .001 \quad 2.952$

Ti $\quad 0.0020 .171 \quad 0.194$

$\mathbf{A l}^{\mathbf{I V}} \quad-\quad-\quad 0.048$

$\begin{array}{llll}\mathbf{A l}^{\mathrm{VI}} & 1.819 & 0.564 & 0.807\end{array}$

$\begin{array}{llll}\mathbf{F e}^{3+} & 0.092 & 1.085 & 0.855\end{array}$

$\begin{array}{llll}\text { Cr } & 0.003 & 0.046 & 0.021\end{array}$

$\begin{array}{llll}\mathbf{F e}^{2+} & 0.143 & 0.197 & 0.118\end{array}$

$\begin{array}{llll}\text { Mg } & - & 0.027 & 0.061\end{array}$

$\begin{array}{llll}\text { Mn } & 0.074 & 0.007 & 0.005\end{array}$

$\begin{array}{llll}\text { Ca } & 2.828 & 2.862 & 2.915\end{array}$

$\begin{array}{llll}\text { Na } & 0.000 & 0.040 & 0.025\end{array}$

Alm

$\begin{array}{llll}\text { And } & 4.79 & 64.00 & 49.37\end{array}$

Gross $92.47 \quad 31.95 \quad 46.91$

$\begin{array}{llll}\text { Pyr } & 0.00 & 1.07 & 2.34\end{array}$

$\begin{array}{llll}\text { Spes } & 2.59 & 0.27 & 0.18\end{array}$

\begin{tabular}{llll} 
Uva & 0.15 & 2.71 & 1.20 \\
\hline
\end{tabular}

\begin{tabular}{lcc}
\hline $\mathbf{W t} \%$ & $\mathbf{7}$ & $\mathbf{8}$ \\
\hline $\mathbf{S i O}_{2}$ & 52.35 & 50.45 \\
$\mathbf{T i O}_{2}$ & bd & 0.00
\end{tabular}

$\begin{array}{llll}\mathrm{K}_{2} \mathrm{O} & 0.02 & \text { bd } & 0.14\end{array}$

28(O) 28(O) 28(O)

$\begin{array}{llll}\text { Si } & 5.845 & 5.694 & 5.508\end{array}$

$\begin{array}{llll}\text { Ti } & 0.006 & 0.005 & 0.002\end{array}$

$\begin{array}{llll}\mathbf{A l}^{\mathbf{I V}} & 2.155 & 2.306 & 2.492\end{array}$

$\begin{array}{llll}\mathbf{A l}^{\mathrm{VI}} & 2.372 & 2.521 & 2.499\end{array}$

$\begin{array}{llll}\text { Cr } & 0.019 & - & 0.040\end{array}$

$\begin{array}{llll}\mathbf{F e}^{2+} & 3.710 & 4.506 & 6.479\end{array}$

$\begin{array}{llll}\text { Mn } & 0.249 & 0.221 & 0.319\end{array}$

$\begin{array}{lllll}\text { Mg } & 5.503 & 4.591 & 2.559\end{array}$

$\begin{array}{lllll}\text { Ca } & 0.007 & 0.036 & 0.047\end{array}$

$\mathrm{Na} \quad-0.004 \quad-$

$\begin{array}{llll}\text { K } & 0.005 & - & 0.041\end{array}$

$\begin{array}{llll}\mathbf{T}\left({ }^{\circ} \mathbf{C}\right) & 285 & 309 & 339\end{array}$
$\mathrm{Al2O}_{3}$ bd 0.57

$\begin{array}{lll}\text { FeO } & 8.44 & 13.10\end{array}$

$\mathrm{Fe}_{2} \mathrm{O}_{3}$ bd bd

$\begin{array}{lll}\mathbf{C r}_{2} \mathbf{O}_{3} & 0.29 & 0.31\end{array}$

MnO 7.33 bd

$\begin{array}{lll}\text { MgO } & 7.52 \quad 13.10\end{array}$

$\begin{array}{lll}\text { CaO } & 23.20 & 21.77\end{array}$

$\mathbf{N a}_{2} \mathbf{O} 0.29$ bd

Total 99.4299 .29

\begin{tabular}{ccc}
\hline $\mathbf{W t} \%$ & $\mathbf{9}$ & $\mathbf{1 0}$ \\
\hline $\mathbf{S i O}_{\mathbf{2}}$ & 34.08 & 33.76 \\
$\mathbf{T i O}_{\mathbf{2}}$ & 0.41 & 0.11 \\
$\mathbf{A l}_{\mathbf{2}} \mathbf{O}_{\mathbf{3}}$ & 12.93 & 13.51 \\
$\mathbf{F e}_{\mathbf{2}} \mathbf{O}_{\mathbf{3}}$ & 15.65 & 14.58 \\
$\mathbf{C r}_{\mathbf{2}} \mathbf{O}_{\mathbf{3}}$ & 4.19 & 4.92 \\
$\mathbf{M n O}$ & 0.64 & 0.24 \\
$\mathbf{M g O}$ & 0.24 & 0.31 \\
$\mathbf{C a O}$ & 13.32 & 13.94 \\
$\mathbf{L a}_{\mathbf{2}} \mathbf{O}_{\mathbf{3}}$ & 7.02 & 7.63 \\
$\mathbf{C e}_{\mathbf{2}} \mathbf{O}_{\mathbf{3}}$ & 9.86 & 9.05 \\
$\mathbf{T o t a l}$ & 98.34 & 98.05
\end{tabular}

$\begin{array}{ccc} & \mathbf{6}(\mathbf{O}) & \mathbf{6}(\mathbf{O}) \\ \mathbf{S i} & 2.044 & 2.031 \\ \mathbf{A l}^{\mathbf{I V}} & - & - \\ \mathbf{T i} & - & - \\ \mathbf{A l}^{\mathbf{V I}} & - & 0.027 \\ \mathbf{F e}^{\mathbf{3}} & - & - \\ \mathbf{C r} & 0.009 & 0.010 \\ \mathbf{F e}^{2+} & 0.276 & 0.151 \\ \mathbf{M n} & 0.243 & 0.056 \\ \mathbf{M g} & 0.437 & 0.786 \\ \mathbf{C a} & 0.970 & 0.939 \\ \mathbf{N a} & 0.022 & - \\ \mathbf{K} & - & -\end{array}$

12.5(O) 12.5(O)

$\begin{array}{lll}\text { Si } & 3.145 & 3.118\end{array}$

Al $\quad 1.405 \quad 1.469$

$\begin{array}{lll}\mathbf{F e}^{3+} & 1.086 & 1.012\end{array}$

$\begin{array}{lll}\text { Mg } & 0.033 & 0.043\end{array}$

$\begin{array}{lll}\text { Ca } & 1.317 & 1.379\end{array}$

$\begin{array}{lll}\text { La } & 0.239 & 0.260\end{array}$

Ce $0.333 \quad 0.306$

Cr $0.141 \quad 0.166$

$\begin{array}{lll}\text { Mn } & 0.021 & 0.008\end{array}$

\begin{tabular}{lll} 
Ti & 0.013 & 0.004 \\
\hline
\end{tabular}

Table 2. Representative microanalyses of pyrophanite (1-4), uranothorianite (5), and thorite $(6,7)$. bd: below detection; (-) not analyzed.

\begin{tabular}{cccccccc}
\hline $\mathrm{wt} \%$ & 1 & 2 & 3 & 4 & 5 & 6 & 7 \\
\hline $\mathrm{SiO}_{2}$ & - & - & - & - & 0.36 & 16.09 & 16.35 \\
$\mathrm{Al}_{2} \mathrm{O}_{3}$ & - & - & - & - & bd & bd & bd \\
$\mathrm{FeO}$ & 11.53 & 14.58 & 9.6 & 10.12 & 0.14 & 0.2 & - \\
$\mathrm{CaO}$ & 0.54 & 0.74 & 0.66 & 0.61 & 0.75 & 1.33 & 0.66 \\
$\mathrm{TiO}_{2}$ & 52.12 & 54.12 & 52.89 & 53.1 & - & - & - \\
$\mathrm{MnO}$ & 33.95 & 30.52 & 36.44 & 35.7 & - & - & - \\
$\mathrm{MgO}$ & bd & bd & 0.25 & bd & - & - & -
\end{tabular}

XLVII. No $1-492$ 


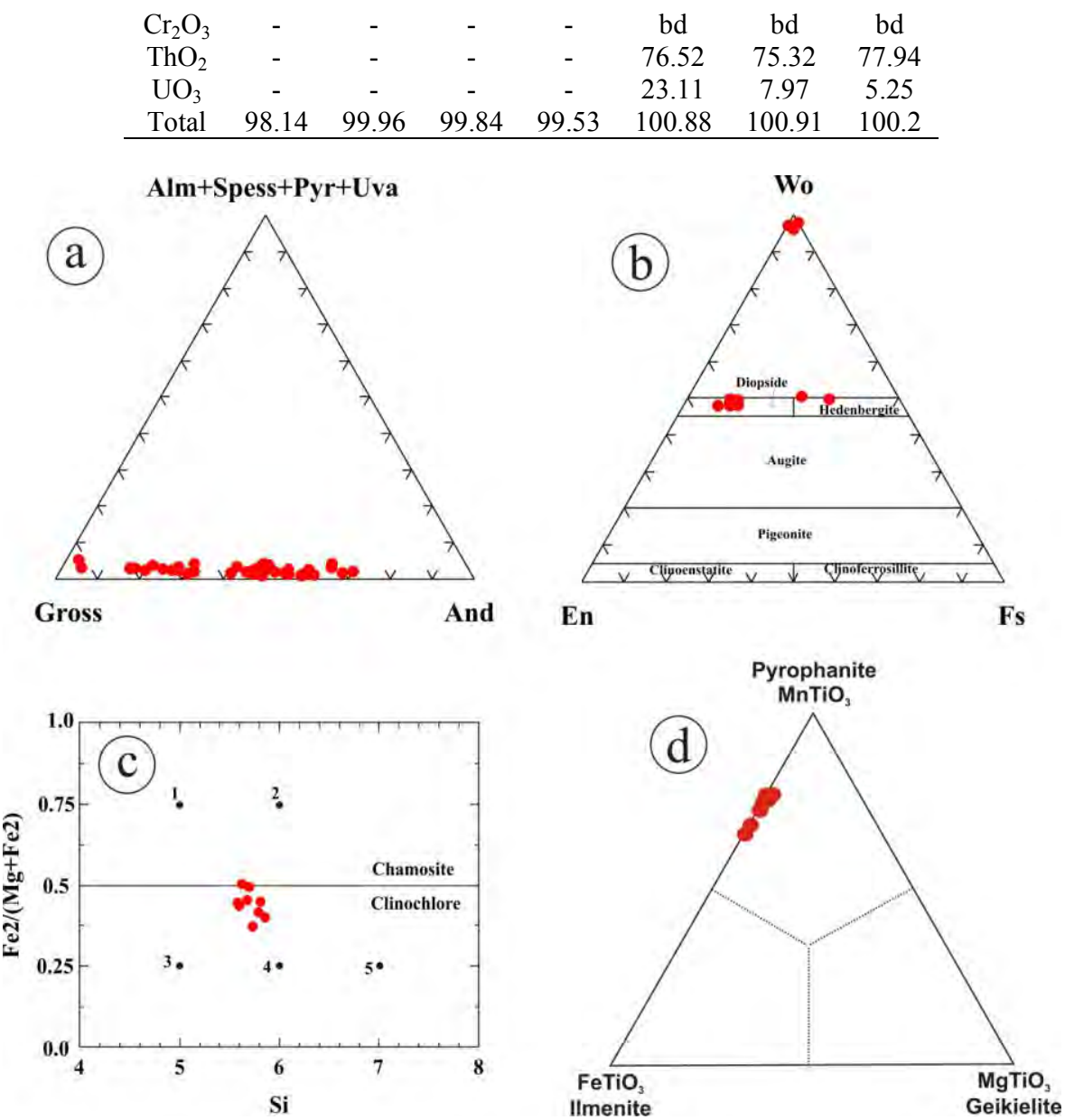

Figure 3 - (a) Ternary Gross-(AIm+Spess+Pyr+Uva)-And diagram demonstrating composition of garnet group minerals; (b) Plot of clinopyroxenes in the ternary Wo-En-Fs diagram;

(c) Classification of chlorite in the binary $\left(\mathrm{Fe}^{2+}+\mathrm{Fe}^{3+}\right)$ vs Si diagram after Mc Leod and

Stanton (1984) (1: Mg-Al chamisite; 2: Mg-chamosite; 3: Fe-Al-clinochlore; 4: Feclinochlore; 5: Fe-Si-clinochlore); (d) Compositions of pyrophanite from the Kimmeria skarn plotted in the $\mathrm{MnTiO}_{3}-\mathrm{FeTiO}_{3}-\mathrm{MgTiO}_{3}$ diagram.

Pyrophanite forms hypidiomorphic crystals with size of up to $60 \mu \mathrm{m}$ and is usually enclosed in garnet or titanite crystals (Figure 2f,h). Representative microanalyses are presented in Table 2 . The analyzed pyrophanites contain 52.1-54.1 wt.\% $\mathrm{TiO}_{2}, 9.6-14.6$ wt. $\% \mathrm{FeO}, 30.5-36.4 \mathrm{wt} \% \mathrm{MnO}$ with minor $\mathrm{CaO}$ content $(0.5-0.7 \mathrm{wt} \%)$ and are characterized as solid solution between pyrophanite-ilmenite (Figure 3d).

Zircon is included in titanite, wollastonite and garnets, forming isolated grains and/or intergrown with uranothorianite (Figure 2c, d, g).

Thorite with formula $(\mathrm{Th}, \mathrm{U}) \mathrm{SiO}_{4}$, is an accesory mineral in the Kimmeria skarn, that crystallizes in the tetragonal system. It is the most common mineral of thorium and is nearly always strongly radioactive. In the Kimmeria skarn, thorite occurs as microscopic inclusions in titanite crystals (Figure 2E). Representative microanalyses are presented in Table 2 indicating that thorite contain 75.3-77.9 wt. $\% \mathrm{ThO}_{2}, 5.2-7.9$ wt. $\% \mathrm{UO}_{3}$ and minor $\mathrm{CaO}$ (up to 1.3 wt.\%). 
Uranothorianite with formula $(\mathrm{Th}, \mathrm{U}) \mathrm{O}_{2}$ is a thorium oxide mineral, which crystallizes in the cubic system. Uranium and REE substiture for Th in the structure. In the Kimmeria skarn the uranothorianite occurs as microscopic inclusions in garnet and titanite crystals, associated with zircon (Figure 2g). A single microanalyses is presented in Table 2 . The analyzed uranothorianite contain 76.5 wt. $\% \mathrm{ThO}_{2}$ and 0.75 wt. $\% \mathrm{CaO}$ and 23.1 wt. $\% \mathrm{UO}_{3}$ substituting for $\mathrm{Th}$.

\section{Discussion and Conclusions}

Using the orthopyroxene-clinopyroxene- and the plagioclase-amphibole geothermometers, Liati (1986) estimated temperatures during the prograde skarn evolution of Kimmeria at about $725^{\circ}$ to $750^{\circ} \mathrm{C}$. The retrograde evolution took place at much lower temperatures (at about $300-350^{\circ} \mathrm{C}$ ), as indicated by the chlorite geothermometry (this study) and resulted in the deposition of quartz, sheelite, epidote, allanite, calcite, hematite and sulfides. Among the prograde skarn minerals of Kimmeria (e.g. garnet, pyroxene, wollastonite, titanite), pyrophanite is a rarity, accompanying Ubearing thorium minerals, as well as rutile and chromite.

Garnets have either anisotropic cores and isotropic periphery or the opposite, suggesting changes either in mineral chemistry or in crystallization conditions. Optical anisotropy in garnets is common in Ca-rich garnets elsewhere, especially those related to contact metamorphism and hydrothermal metasomatism. According to Allen and Buseck (1988), several hypotheses have been proposed for optical anisotropy, but none of them is totally acceptable. These hypotheses include plastic deformation and crystal lattice deformation (Lessing and Standish, 1973; Kitamura and Komatsu, 1978). Other researchers suggest that anisotropic areas in garnets may be attributed to the existence of $\mathrm{Al}$ and $\mathrm{Fe}^{3+}$ in octahedral sites (Takouchi et al., 1982) or the presence of $\mathrm{OH}$ in cubic coordination (Rossman and Aines, 1986).

In the Kimmeria skarn, pyrophanite occurs as a minor constituent included in garnet and titanite accompanying U-bearing thorium minerals (uranothorianite, thorite) and rutile. This suggests that pyrophanite forms part of the prograde assemblage of Kimmeria skarn. In the studied pyrophanites, a substitution of $\mathrm{Mn}^{2+}$ by $\mathrm{Fe}^{2+}$ was observed, corresponding to a significant ilmenite component (about $20-30 \%$ ). The Mn, which is necessary for the formation of pyrophanite, is probably of magmatic origin and/or may have been derived from the amphibolite host-rocks. The alteration of pyrophanite and rutile to titanite (hematite and chalcopyrite) indicates a trend towards more oxidizing conditions, since pyrophanite similarly to ilmenite mostly occurs in reducing assemblages (Nayak and Mohapatra, 1998; Iliopoulos 2005) and titanite is indicative for more oxidizing conditions (e.g. Xyrouchakis and Lindslay, 1998; Broska et al., 2007). Moderate $\mathrm{fO}_{2}-\mathrm{fS}_{2}$ conditions have been also suggested by Skarpelis and Liati (1991) based on the coexistence of chalcopyrite-bornite-wollastonite-andradite in the prograde skarn paragenesis at Kimmeria. Increasing values of $f \mathrm{O}_{2}$ in the fluid, probably due to increasing participation of meteoric water in the retrograde skarn evolution at Kimmeria skarn, may have caused deposition of hematite and major introduction of sulfides, in common to other skarn ores elsewhere (Meinert et al., 2005). The presence of thorium-bearing minerals (e.g. uranothorianite and thorite) and zircon accompanying pyrophanite are indicative of a magmatic contribution. Thorite and uranothorianite from the Kimmeria skarn contain significant amounts of $\mathrm{UO}_{3}$ (up to 23 wt. \%) substituting for thorium in the structure. This study verifies previous work by Karavassili et al. (2005) who measured high radioactivity values in fresh monzodiorites of Kimmeria and related them to the presence of thorium minerals in the granitoid body.

\section{Acknowledgments}

An anonymous reviewer and Prof. Dr. E. Manoutsoglou are greatly acknowledged for their helpful and constructive comments, which improved the initial manuscript. 


\section{References}

Allen F. and Buseck P. 1988. XRD, FTIR, and TEM studies of optically anisotropic grossular garnets, Am. Mineral., 73, 568-584.

Barr S.R., Temperley S. and Tarney J. 1999. Lateral growth of the continental crust through deep level subduction-accretion: a reevaluation of central Greek Rhodope, Lithos, 46, 69-94.

Bauer C., Rubatto D., Krenn K., Proyer A. and Hoinkes G. 2007. A zircon study from the Rhodope metamorphic complex, N-Greece: Time record of a multistage evolution, Lithos 99, 207-228.

Broska I., Harlov D., Tropper P. and Siman P. 2007. Formation of magmatic titanite and titaniteilmenite phase relations during granite alteration in the Tribec Mountains, Western Carpathians, Slovakia, Lithos, 95, 58-71.

Cathlelineau M. 1988. Cation size occupancy in chlorites and illites as a function of temperature, Clay Minerals, 23, 471-485.

Del Moro A., Innocenti F., Kyriakopoulos C., Manetti P. and Papadopoulos P. 1988. Tertiary granitoids from Thrace (Northern Greece): Sr isotopic and petrochemical data, N. Jb. Mineral. Abh. 159, 113-135.

Dimitriadis S. and Soldatos K. 1978. Optical and structural properties of adularia from Xanthi and Ouranoupolis, Greece, and their interpretation, N. Jb. Miner. Abh., 133, 88-105.

Gautier P. and Brun J.P. 1994. Ductile crust exhumation and extensional detachments in the central Aegean (Cyclades and Evia Islands), Geod. Acta 7, 57-85.

Georgiadis I.K., Tzamos E., Kantiranis N., Papadopoulou L., Tsirambidis A. and Filippidis A. 2012. On the mineralogy of the wollastonite from Xanthi-Kimmeria (Thrace, Greece), Soldatos Special Vol., Aristotle Univ. Thessaloniki, 101, 17-21.

Hamberg A. 1890. Uber die Manganophylle von der Grube Harstigen bei Pajsberg in Vermland, Geol. For. Forh., Stockholm, 133, 567-579.

Iliopoulos I. 2005. Petrogenesis of metamorphic rocks at Ikaria island, Unpub. Ph.D. thesis, Univ. Patras, 592 pp (in Greek).

Jolivet L. and Brun J.P. 2010 Cenozoic geodynamic evolution of the Aegean region, Int. J. Earth. Sci., 99, 109-138.

Karavasili E., Christofides G., Papastefanou C., Koroneos A. and Stoulos S. 2005. Mineralogy, Petrography and Radioactivity of Greek Granites, Proceedings of the 2nd Congress of the Committee of the Econ. Geol., Mineral. \& Geochem. of the Geol. Soc. Greece, Thessaloniki, 123-132.

Kitamura K., and Komatsu H. 1978. Optical anisotropy Associated with growth striation of yttrium garnet, Kristallographie and Technik, 3, 811-816.

Krenn K., Bauer C., Proyer A., Mposkos E., Hoinkes G. 2008. Fluid entrapment and reequilibration during subduction and exhumation: A case study from the high-grade Nestos shear zone, Central Rhodope, Greece, Lithos, 104, 33-53.

Lessing P. and Standish R.P. 1973. Zoned garnet from Crested Butte, Colorado, Am. Mineral., 58, 840-842.

Liati A. 1986. Regional metamorphism and overprinting contact metamorphism of the Rhodope zone, near Xanthi (N. Greece). Petrology, Geochemistry, Geochronology: Unpub. Ph.D. thesis, Univ. Braunschweig, 186 pp.

Liati A. and Seidel E. 1996. Metamorphic evolution and geochemistry of kyanite-eclogites in central Rhodope, northern Greece, Contrib. Mineral. Petrol. 123, 293-307.

Marchev P. Kaiser-Rohrmeier, M.; Heinrich, Ch.; Ovtcharova, M.; von Quadt, A.; Raicheva, R. 2005. Hydrothermal ore deposits related to post-orogenic extentional magmatism and core complex formation: the Rhodope Massif of Bulgaria and Greece, Ore Geol. Rev., 27, 53-89

Mc Leod R.L. and Stanton R.L. 1984. Phyllosilicates and associated minerals in some Paleozoic stratiform sulfide deposits of southern Australia, Econ. Geol. 79, 1-22.

Meinert L.D., Dipple G.M. and Nicolescu S. 2005. World skarn deposits, Econ. Geol., 100, 299336.

$\underline{\text { XLVII. No } 1-495}$ 
Morimoto N., Fabries J., Ferguson A.K., Ginzburg I.V., Ross M., Seifert F.A., Zussman J., Aoki K. and Gottardi G. 1988. Nomenclature of pyroxenes, Am. Mineral., 73, 1123-1133

Mposkos E.D. and Kostopoulos D.K. 2001. Diamond, former coesite and supersilicic garnet in metasedimentary rocks from the Greek Rhodope: a new ultrahigh-pressure metamorphic province established, Earth Plan. Sci. Lett., 192, 497-506.

Mposkos E. and Krohe A. 2006. Pressure-temperature-deformation paths of closely associated ultra-high-pressure (diamond-bearing) crustal and mantle rocks of the Kimi complex: implications for the tectonic history of the Rhodope Mountains, northern Greece, Can. J. Earth Sci., 43, 1755-1776.

Nayak B.R. and Mohapatra B.K. 1998. Two morphologies of pyrophanite in Mn-rich assemblages, Gangpur Group, India, Mineral. Mag. 62, 847-856.

Papanikolaou D. 1984. The three metamorphic belts of the Hellenides: A review and a kinematic interpretation, Spec. Publ. Geol. Soc. London, 17, 551-561.

Papanikolaou D. and Panagopoulos A. 1981. On the structural style of southern Rhodope, Geol. Balcan., 11, 13-22.

Rossman G.R. and Aines R.D. 1986. Spectroscopy of a birefringent grossular frorn Asbestos, Quebec, Canada, Am. Mineral., 71, 779-780.

Reischmann T. and Kostopoulos D. 2007. Terrane accretion in the internal Hellenides, Geoph. Res. Abstracts, Vol. 9.

Ricou L.-E., Burg J.P., Godfriaux I. and Ivanov Z. 1998. Rhodope and Vardar: the metamorphic and the olistostromic paired belts related to the Cretaceous subduction under Europe, Geod. Acta 11, 285-309.

Sergi A. 1997. Mafic microgranular enclaves from the Xanthi pluton (Northern Greece): An example of mafic-felsic magma interaction, Mineral. Petrol, 61, 97-117.

Skarpelis N. and Liati A. 1991. Wollastonite and associated copper mineralization in the contact metamorphic aureole fo Kimmeria, Xanthi, N. Greece, Bull. Geol. Soc. Greece, 25/2, 369377.

Takouchi Y., Haga N, Umizu S., and Sato G. 1982. The derivative structure ofsilicate garnets in grandite, Zeitschrift Kristallographie, 158, 53-99.

Turpaud P. and Reischmann T. 2010. Characterisation of igneous terranes by zircon dating: implications for UHP occurrences and suture identification in the Central Rhodope, northern Greece, Int. J. Earth Sci., 99, 567-591.

Zaccarini F., Garuti G., Ortiz-Suarez A. and Carugno-Duran A., 2004. The paragenesis of pyrophanite from Sierra de Comechingones, Córdoba, Argentina, Can. Mineral. 42, 155168.

Xyrouchakis D. and Lindsley D.H. 1998. Equilibria among titanite, hedenbergite, fayalit, quartz, ilmenite, and magnetite: Experiments and internally consistent thermodynamic data for titanite, Am. Mineral., 83, 712-725. 